\title{
Identification of the HIT-45 protein from Trypanosoma brucei as an FHIT protein/dinucleoside triphosphatase: Substrate specificity studies on the recombinant and endogenous proteins
}

\author{
HIREN BANERJEE, ${ }^{1,2}$ JENNIFER B. PALENCHAR, ${ }^{3}$ MACIEJ LUKASZEWICZ, ${ }^{4}$ ELZBIETA BOJARSKA, ${ }^{4}$ \\ JANUSZ STEPINSKI, ${ }^{4}$ JACEK JEMIELITY, ${ }^{4}$ ANDRZEJ GURANOWSKI, ${ }^{5}$ STEPHANIE NG, ${ }^{1}$ DAVID A. WAH, ${ }^{6}$ \\ EDWARD DARZYNKIEWICZ, ${ }^{4}$ and VIVIAN BELLOFATTO ${ }^{1}$ \\ ${ }^{1}$ Department of Microbiology and Molecular Genetics, University of Medicine and Dentistry-New Jersey Medical School, Newark, \\ New Jersey 07103, USA \\ ${ }^{2}$ Institute of Parasitology, McGill University, Ste-Anne de Bellevue, Quebec H9X 3V9, Canada \\ ${ }^{3}$ Department of Chemistry, Villanova University, Villanova, Pennsylvania 19085, USA \\ ${ }^{4}$ Department of Biophysics, Institute of Experimental Physics, Warsaw University, 02-089 Warsaw, Poland \\ ${ }^{5}$ Department of Biochemistry and Biotechnology, University of Life Sciences, 60-637 Poznan, Poland \\ ${ }^{6}$ Public Health Research Institute Center, University of Medicine and Dentistry-New Jersey Medical School, Newark, New Jersey 07103, USA
}

\begin{abstract}
A new member of the FHIT protein family, designated HIT-45, has been identified in the African trypanosome Trypanosoma brucei. Recombinant HIT-45 proteins were purified from trypanosomal and bacterial protein expression systems and analyzed for substrate specificity using various dinucleoside polyphosphates, including those that contain the $5^{\prime}$-mRNA cap, i.e., $m^{7}$ GMP. This enzyme exhibited typical dinucleoside triphosphatase activity (EC 3.6.1.29), having its highest specificity for diadenosine triphosphate (ApppA). However, the trypanosome enzyme contains a unique amino-terminal extension, and hydrolysis of cap dinucleotides with monomethylated guanosine or dimethylated guanosine always yielded $\mathbf{m}^{7}$ GMP (or $\left.\mathbf{m}^{2,7} \mathrm{GMP}\right)$ as one of the reaction products. Interestingly, $\mathrm{m}^{7} \mathrm{Gpppm}_{3}{ }^{\mathrm{N} 6}, \mathrm{N6}, \mathrm{2}^{\prime} \mathrm{O} A$ was preferred among the methylated substrates. This hypermethylated dinucleotide is unique to trypanosomes and may be an intermediate in the decay of cap 4, i.e., $\mathrm{m}^{7} \mathrm{Gpppm}_{3}{ }^{\mathrm{N}}$, $\mathrm{NG}^{6}, 2^{\prime} \mathrm{O}$ $\mathrm{Apm}^{2^{\prime} \mathrm{O}} \mathrm{Apm}^{2^{\prime} \mathrm{O}} \mathrm{Cpm}_{2}{ }^{\mathrm{N} 3,2^{\prime} \mathrm{O}} \mathrm{U}$, that occurs in these organisms.
\end{abstract}

Keywords: RNA processing; trypanosomes; FHIT proteins; cap-containing nucleotides; dinucleoside triphosphatase activity

\section{INTRODUCTION}

Gene expression in trypanosomes is controlled in part by cellular processes that regulate cytoplasmic steadystate mRNA levels (Clayton and Shapira 2007). Many of the regulatory proteins recognize mRNA-specific modifications. For example, mRNA decay pathways initiate at either the $5^{\prime}$ end $\mathrm{m}^{7} \mathrm{G}$-cap or the $3^{\prime}$ end polyadenylated tail (Shatkin and Manley 2000; Shuman 2002). The most

Reprint requests to: Vivian Bellofatto, Department of Microbiology and Molecular Genetics, University of Medicine and Dentistry-New Jersey Medical School, Newark, NJ 07103, USA; e-mail: bellofat@umdnj.edu; fax: (973) 972-3644; or Edward Darzynkiewicz, Department of Biophysics, Institute of Experimental Physics, Warsaw University, 02-089 Warsaw, Poland; e-mail: darzynkiewicz@neostrada.pl.

Article published online ahead of print. Article and publication date are at http://www.rnajournal.org/cgi/doi/10.1261/rna.1426609. hypermethylated $\mathrm{m}^{7} \mathrm{G}$ - or cap-containing structure found in nature is the trypanosome cap $4\left(\mathrm{~m}^{7} \mathrm{Gpppm}_{3}{ }^{\mathrm{N} 6}, \mathrm{~N} 6,2^{\prime} \mathrm{O}\right.$ $\left.\mathrm{Apm}^{2^{\prime} \mathrm{O}} \mathrm{Apm}^{2^{\prime} \mathrm{O}} \mathrm{C} \mathrm{pm}_{2}{ }^{\mathrm{N} 3},{ }^{\prime} \mathrm{O} \mathrm{U}\right)$. It contains base methylations on the first and fourth transcribed nucleotides and $2^{\prime}-O$-methylations on the ribose of all four transcribed nucleotides (Bangs et al. 1992). Little is known about how trypanosomes catabolize the hypermethylated $\mathrm{m}^{7} \mathrm{G}$-cap within their mRNAs.

Extensive analyses of yeast and mammalian mRNA decay pathways reveal that $\mathrm{m}^{7} \mathrm{G}$-capped mRNA first loses its $3^{\prime}$ polyadenylated tail through the action of specific deadenylases. One fate of this mRNA is $3^{\prime}-5^{\prime}$ exonucleolytic decay mediated by the exosome, leaving a $\mathrm{m}^{7} \mathrm{G}$-capped dinucleotide (Mitchell et al. 1997; Anderson and Parker 1998). This $\mathrm{m}^{7} \mathrm{GpppX}$ dinucleotide is hydrolyzed by a scavenger nuclease, DcpS, that catalyzes the cleavage of the 
$\gamma-\beta$ pyrophosphate bond of the $5^{\prime}, 5^{\prime \prime \prime}-\mathrm{P}^{1}, \mathrm{P}^{3}$-triphosphate bridge to yield $\mathrm{pm}^{7} \mathrm{G}$ and $\mathrm{ppX}$ (Nuss et al. 1975; Wang and Kiledjian 2001; Liu et al. 2002). DcpS proteins constitute their own branch within the histidine triad (HIT) family of hydrolases and include human DcpS, Saccharomyces cerevisiae Dcs1p and Dcs2p, Caenorhabditis elegans dcs-1, and Schizosaccharomyces pombe Nhm1p (Fig. 1).

Bioinformatic and biochemical analyses have uncovered deadenylase activities and an exosome complex that participate in mRNA decay in trypanosomes (Estevez et al. 2001; Milone et al. 2004; Clayton and Shapira 2007). However, the absence of a trypanosome DcpS ortholog motivated us to determine if a unique Trypanosoma brucei HIT protein catabolizes cap-containing (oligo)nucleotides. The T. brucei database revealed four HIT proteins. Interestingly, only one protein, HIT-45, remotely resembled DcpS in that it contained an N-terminal extension in addition to its C-terminal HIT motif. Detailed analysis allowed us to assign this protein to the Fhit branch of HIT proteins and to demonstrate that HIT-45 is active on $\mathrm{Np}_{\mathrm{n}} \mathrm{Ns}$, including cap-containing molecules and $\mathrm{m}^{7} \mathrm{Gpppm}_{3}{ }^{\mathrm{N} 6},{ }^{\mathrm{N}} 6,2^{\prime} \mathrm{O} A$, which contains the hypermethylated adenosine only found within the trypanosome cap 4 .

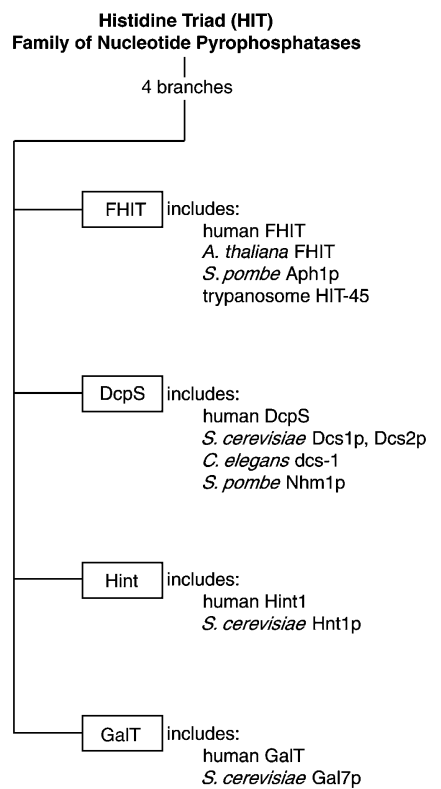

FIGURE 1. Diagram of histidine triad superfamily of nucleotide pyrophosphatases. The triad is defined by $\mathrm{H} \psi \mathrm{H} \psi \mathrm{H} \psi \psi$ (where $\psi$ is a hydrophobic amino acid) (Seraphin 1992). Representative proteins within each group are limited to those for which detailed functional studies have been published. References: Human FHIT (Brenner 2002); S. pombe Aphlp (Ingram and Barnes 2000), A. thaliana FHIT (Guranowski et al. 2008), trypanosome HIT-45 (this paper), human DcpS (Gu et al. 2004), S. cerevisiae Dcs1p2p (Liu et al. 2002), C. elegans dcs-1 (Cohen et al. 2004), S. pombe Nhm1p (Salehi et al. 2002), human Hint1 (Brenner et al. 1997), S. cerevisiae Hntlp and Gal7p (Tajima et al. 1985).

\section{RESULTS}

\section{HIT-45 is present exclusively in the Tri-Tryp genomes and is a novel FHIT family member}

There are no obvious homologs of the decapping enzyme DcpS in the Tri-Tryp database (genomic sequences of $T$. brucei, T. cruzi, and Leishmania major) (Berriman et al. 2005; El-Sayed et al. 2005; Ivens et al. 2005). Given that DcpS is a member of the HIT family of hydrolases, we searched in T. brucei for a candidate protein with a HIT motif that could function as a nucleotide-specific hydrolase (Lima et al. 1997; Brenner 2002). The T. brucei database has four HIT motif-containing proteins. Two proteins were not pursued as they contain significant homology with copper oxidase and kinesin (Tb927.3.2870 and Tb927.3.3400, respectively). One of the other two proteins, Tb927.7.4480, is a member of the Hint branch of HIT proteins that possess AMP-lysine hydrolase activity (Fig. 1; Krakowiak et al. 2004), making it an unlikely component of mRNA catabolism. Thus, we chose to investigate HIT-45 (Tb927.8.2980), as its primary amino acid sequence is arranged similarly to DcpS in that it contained an $\mathrm{N}$-terminal extension followed by a C-terminal HIT motif.

An amino acid alignment of the HIT-45 orthologs present in T. brucei, T. cruzi, and L. major to members of the HIT protein family has revealed that it most closely resembles proteins within the Fhit branch. Two motifs characteristic for Fhit proteins (motif I: M/LVNxKPV/ IxPxHL/VM/LV/IxPxR, and motif II: I/V/MQQ/DGxxAGQT/ $\mathrm{SVP} / \mathrm{E} / \mathrm{KHL} / \mathrm{VHV} / \mathrm{THV} / \mathrm{I} \mathrm{I} / \mathrm{LP}$; embedded in this motif is the histidine triad) are well conserved within trypanosome proteins (Supplemental Fig. S1; Barnes et al. 1996; Pace et al. 1998; Brenner 2002; Ingram et al. 2003). These motifs occur within the C-terminus of HIT-45 and align with human FHIT, the founding member of the Fhit branch of HIT proteins (Klein et al. 1998; Brenner et al. 1999; Brenner 2002; Pekarsky et al. 2002). However, HIT-45 differs in four features from other proteins in the Fhit branch of the HIT family of hydrolases as follows.

First, HIT-45 has an N-terminal extension that is unique to the trypanosome family (Fig. 2). The only other $\mathrm{N}$-terminal extension found on an Fhit protein is in worms and flies, where an $\mathrm{N}$-terminal nitrilase is fused to a C-terminal Fhit protein (Pekarsky et al. 1998).

Second, the highly conserved motifs I and II in the C terminus of HIT-45 are separated by a stretch of amino acids that is longer than the region that normally separates these two motifs in the Fhit branch of HIT proteins. Interestingly, this sequence shares no significant homology among the T. brucei, T. cruzi, and L. major HIT-45 orthologs (although several glycines and two adjacent serines seem to be similarly arranged), and it is approximately two times longer in T. brucei than in the other trypanosomes (Supplemental Fig. S1). 
Trypanosome HIT-45 and Human FHIT proteins
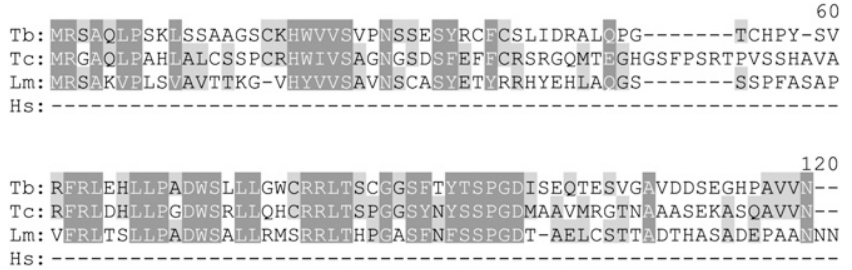

Lm: VERIT TLLPADWSALIRMSRRIMHPGASENESSPGDT-AELCSTTMDTHASADEPAANNN

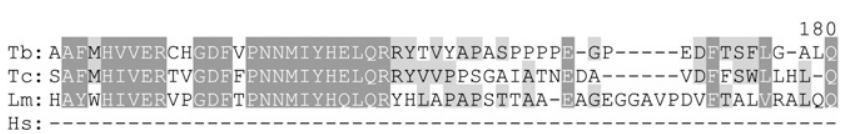

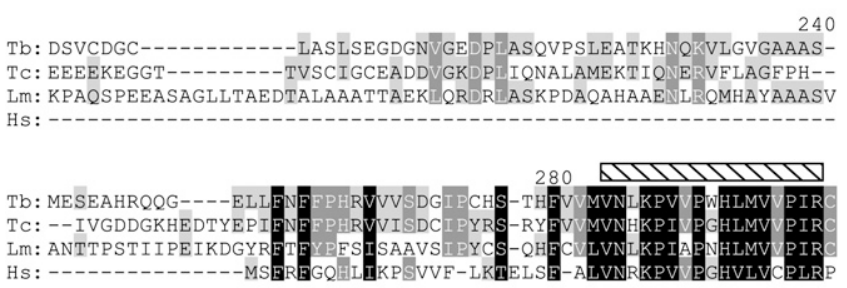

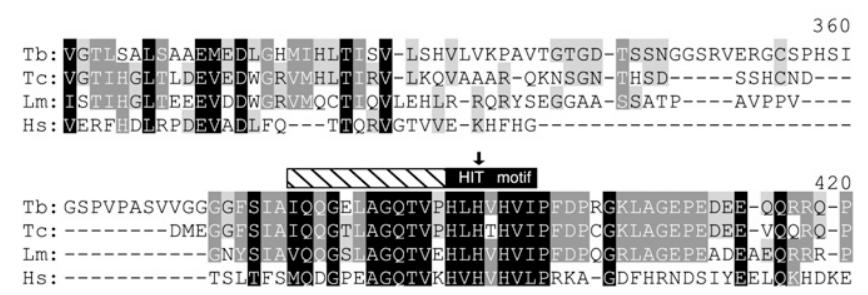

FIGURE 2. Multiple sequence alignment of trypanosome HIT-45 and the human FHIT protein. The entire amino acid sequences of HIT-45 from T. brucei (Tb, Tb927.8.2980), T. cruzi (Tc, Tc00.1047053509857.20), and L. major (LmjF23.1055, with the correct $\mathrm{N}$-terminal extension) $\mathrm{N}$ termini are shown. The human FHIT protein (gene: P49789, protein: EC 3.6.1.29) is included because this protein contains the canonical fHIT motif (striped boxes) that define FHIT orthologs. (Black shading) High conservation, (gray shading with white lettering) $75 \%$ conservation, (gray shading with black letters) $50 \%$ conservation. (Box) HIT motif. The C termini of the proteins are not included. (Arrow) Internal histidine that was mutated.

Third, the highly conserved motif II in the C terminus of HIT-45 is within a longer sequence that is conserved among T. brucei, T. cruzi, and L. major. Specifically, motif II is flanked at its $\mathrm{N}$ terminus by four conserved amino acids (F/Y SIA) and at its $\mathrm{C}$ terminus by 25 conserved amino acids (FDPxG K/R LAGEPExDE E/A xQ R/Q R Q/R P P/C RT) (Supplemental Fig. S2). As a separate point, this C-terminal conserved region is markedly different from the corresponding region that flanks motif II in the Fhit proteins described to date (human FHIT, Arabidopsis thaliana FHIT, S. pombe Aph1, S. cerevisiae Hnt2). HIT-45 motif II's C-terminal extension begins with a phenylalanine that is followed by aspartic acid, then (separated by $\mathrm{PxG}$ ) by either positively charged lysine or arginine, and finally by conserved regions (patches) of negatively and positively charged residues (Supplemental Fig. S2). In contrast to
HIT-45, other Fhit proteins contain a motif II that is followed by two positively charged resides and then less conserved negatively charged amino acids.

Fourth, the highly conserved motif II in HIT-45 contains a leucine located seven residues $\mathrm{N}$-terminal to the first histidine in the HIT triad (Supplemental Fig. S2). In contrast, other Fhit proteins contain an aspartic acid or a glutamic acid. This is interesting because in the case of the DcpS branch of HIT proteins, which comprise the scavenger decapping enzymes, a conserved histidine (H268 of human DcpS) at this position relative to the HIT triad is essential for decapping activity (Gu et al. 2004). Thus, we conclude that HIT-45 is a unique HIT protein and a novel member of the FHIT branch of hydrolases. We predict that the specific amino acid sequence of HIT-45 may influence its enzymatic activities in the parasite.

\section{HIT-45 requires its HIT motif to hydrolyze dinucleoside 5', 5'"'-P $\mathbf{P}^{1}, \mathrm{P}^{\mathbf{3}}$-triphosphates}

Recombinant HIT-45 protein was purified and tested for specific hydrolase activity using $\mathrm{m}^{7} \mathrm{GpppG}$ (Fig. 3). The enzyme hydrolyzed only the anhydride bond between the $\gamma$ and $\beta$ phosphates within the tripolyphosphate bridge to produce ${ }^{\star} \mathrm{pm}^{7} \mathrm{G}$ from $\mathrm{m}^{7} \mathrm{G}^{\star}$ pppG (Fig. 3B,C; asterisk indicates ${ }^{32} \mathrm{P}$ at the $\gamma$-phosphate) in a way characteristic of the DcpS branch of the HIT family of proteins. HIT motifcontaining proteins rely on their central histidine for enzymatic activity. To determine whether the HIT motif within HIT-45 conferred enzymatic activity to the protein, a H355N mutant enzyme was tested for activity on $\mathrm{m}^{7} \mathrm{G}^{*} \mathrm{pppG}$ and was found to be inactive (Fig. 3A,D). Thus, HIT-45 was able to cleave a capped dinucleotide, recognizing it as a substrate using the central histidine within the HIT motif for catalytic activity. We conclude that HIT- 45 is a bona fide HIT family member.

To determine if endogenous HIT-45 has a similar activity to the recombinant protein, $T$. brucei was stably transfected with a tandem affinity purification (TAP) tagged HIT-45 under the inducible control of a transgenic T7 RNA polymerase-dependent promoter. The dual chromatography steps used for protein purification and the elution profiles are shown in Figure 4A. Enzyme activity purified with the HIT-45 protein, as expected (Fig. 4B). A highly enriched HIT- 45 fraction was active on $\mathrm{m}^{7} \mathrm{G}^{\star} \mathrm{pppG}$, releasing ${ }^{*} \mathrm{pm}^{7} \mathrm{G}$ (Fig. 4B, fraction $\mathrm{E}-2$ ). This enzyme fraction converted substrate to ${ }^{*} \mathrm{pm}^{7} \mathrm{G}$ in a time-dependent fashion (Fig. 4C).

\section{Specificity of HIT-45 toward methylated and unmethylated dinucleoside $5^{\prime}, 5^{\prime \prime \prime}-\mathrm{P}^{\mathbf{1}}$, $\mathbf{P}^{3}$ - triphosphates}

Several dinucleotides modified within the oligophosphate bridge, ribose ring, and base moiety were used to study the 
A
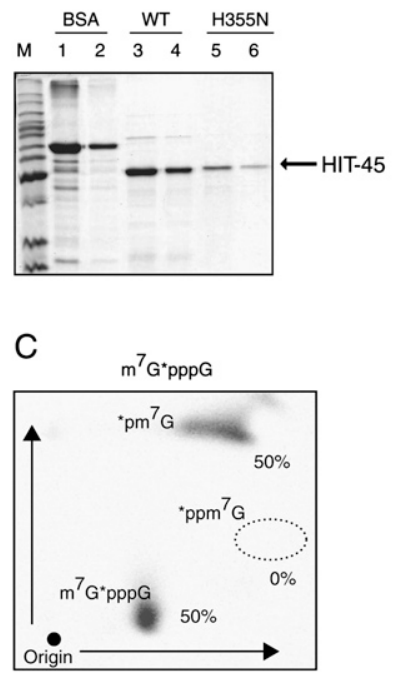

D

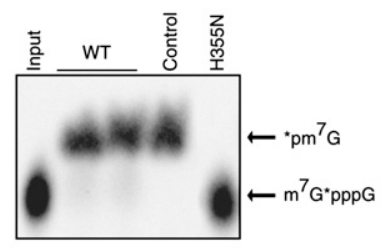

FIGURE 3. HIT-45 requires its HIT motif to function as a nucleotide pyrophosphatase. $(A)$ Analysis of the purity of recombinant wild-type and mutant T. brucei HIT-45 proteins, synthesized in E. coli, and containing N-terminal $\mathrm{His}_{6}$-tags. Proteins were separated by SDSPAGE and stained with Coomassie brilliant blue. (Lanes 1,2) BSA (5 and $1 \mu \mathrm{g}$ ) to assess protein concentrations; (lanes 3,4) TbHIT-45 wild-type (WT) (10 and $5 \mu \mathrm{L}$ ); (lanes 5,6) $\mathrm{H} 355 \mathrm{~N}$ mutant protein $(10$ and $5 \mu \mathrm{L}$ ). (Arrow) Purified proteins. Protein size markers are the Benchmark ladder (Invitrogen). (B) Thin-layer chromatogram (TLC) of products from $\mathrm{m}^{7} \mathrm{G}^{*} \mathrm{pppG}$ hydrolysis by HIT-45. (Input lane) $\mathrm{m}^{7} \mathrm{G}^{*} \mathrm{pppG}$. (C) Two-dimensional TLC analysis of HIT-45 hydrolysis of $\mathrm{m}^{7} \mathrm{G}^{*} \mathrm{pppG}$. (D) TLC analysis of $\mathrm{m}^{7} \mathrm{G}^{*} \mathrm{pppG}$ substrate incubated with wild-type HIT-45 and HIT-45 H355N. (Control lane) Human DcpS that converts $\mathrm{m}^{7} \mathrm{G}^{\star} \mathrm{pppG}$ to $\mathrm{m}^{7} \mathrm{G}^{\star} \mathrm{p}$.

substrate specificity of HIT-45. The kinetics of HIT-45 hydrolysis of various substrates and the resulting products identified by HPLC analysis are shown in Table 1. Most of the investigated compounds were cleaved by HIT- 45 with formation of nucleoside monophosphates as one of the reaction products. Nonmethylated dinucleotides ApppA and GpppG were hydrolyzed, yielding $\mathrm{pA}+\mathrm{ppA}$ and $\mathrm{pG}+\mathrm{ppG}$, respectively. Cleavage of the hybrid dinucleotide ApppG gave two product pairs, $\mathrm{pA}+\mathrm{ppG}$ and $\mathrm{pG}+\mathrm{ppA}$, with a preference for the $\mathrm{pA}+\mathrm{ppG}$ pair.

Cap analogs were also good substrates for HIT-45. The preference of cleavage of these compounds strongly depends on the position and number of methyl groups. Mono- and dimethylated dinucleoside triphosphates $\left(\mathrm{m}^{7} \mathrm{GpppG}\right.$ and $\mathrm{m}_{2}{ }^{\mathrm{N} 2,7} \mathrm{GpppG}$ ) were hydrolyzed, with formation of methylated monophosphates $\left(\mathrm{pm}^{7} \mathrm{G}\right.$ or $\mathrm{pm}_{2}{ }^{\mathrm{N} 2,7} \mathrm{G}$, respectively) and nonmethylated diphosphate (ppG). $\mathrm{pG}$ and $\mathrm{ppm}^{7} \mathrm{G}$ (or $\mathrm{ppm}_{2}{ }^{\mathrm{N} 2,7} \mathrm{G}$ ) were not produced. In contrast, $\mathrm{m}^{7} \mathrm{GpppA}$ was cleaved, giving two product pairs, $\mathrm{pm}^{7} \mathrm{G}+\mathrm{ppA}$ and $\mathrm{ppm}^{7} \mathrm{G}+\mathrm{pA}$, with a significantly higher yield of the $\mathrm{pm}^{7} \mathrm{G}+\mathrm{ppA}$ pair. This indicates a preferential recognition of methylated bases by HIT-45. Ribose modification of the cap analog $\mathrm{m}^{7} \mathrm{GpppG}$, produced by introducing a 2'-O-methyl substitution, changed the cleavage preference; hydrolysis products of $\mathrm{m}_{2}{ }^{7,2, \mathrm{O}} \mathrm{GpppG}$ were identified as $\mathrm{pG}$ and $\mathrm{ppm}_{2}{ }^{7,2^{\prime} \mathrm{O}} \mathrm{G}$. Trimethylated dinucleotides $\mathrm{m}_{3}{ }^{\mathrm{N} 2, \mathrm{~N} 2,7} \mathrm{GpppG}(\mathrm{A})$ were degraded in a similar way, yielding nonmethylated monophosphates $\mathrm{pG}(\mathrm{pA})$ and $\mathrm{ppm}_{3}{ }^{\mathrm{N} 2, \mathrm{~N} 2,7} \mathrm{G}$. Interestingly, enzyme recognition occurred when both bases in a dinucleotide were modified by a methyl group $\left(\mathrm{m}^{7} \mathrm{Gpppm}{ }^{\mathrm{N} 6} \mathrm{~A}, \mathrm{~m}^{7} \mathrm{Gpppm}{ }^{7} \mathrm{G}\right)$; however, the properties of these substrates were significantly different. $\mathrm{m}^{7} \mathrm{Gpppm}^{7} \mathrm{G}$ was a poor substrate for HIT-45, with a very low rate of hydrolysis $(<1 \%)$ in comparison with $\mathrm{m}^{7} \mathrm{Gpppm}^{\mathrm{N} 6} \mathrm{~A}$ and other tested capcontaining substrates.

A cap-containing analog with a methylene group instead of oxygen between the $\beta$ and $\gamma$ phosphorus atoms $\left(\mathrm{m}^{7} \mathrm{GpCH}_{2} \mathrm{ppG}\right)$ was revealed to be a nonhydrolyzable compound, while $\mathrm{m}^{7} \mathrm{GppCH}_{2} \mathrm{pG}$ underwent very slow hydrolysis (similar to that of $\mathrm{m}^{7} \mathrm{Gpppm} \mathrm{m}^{7} \mathrm{G}$ ), with formation of $\mathrm{pm}^{7} \mathrm{G}$ and $\mathrm{pCH}_{2} \mathrm{pG}$.

The hypermethylated dinucleotide $\mathrm{m}^{7} \mathrm{Gpppm}_{3}{ }^{\mathrm{N} 6, \mathrm{~N} 6,2^{\prime} \mathrm{O}} \mathrm{A}$, which is a truncated form of cap 4, uniquely found in trypanosomes, was also hydrolyzed by HIT-45 to yield two products, $\mathrm{pm}^{7} \mathrm{G}$ and $\mathrm{ppm}_{3}{ }^{\mathrm{N} 6, \mathrm{~N} 6,2^{\prime} \mathrm{O}} \mathrm{A}$. This hypermethylated dinucleotide was also a preferred substrate for HIT- 45 among all tested methylated dinucleoside triphosphates (it had the lowest $K_{0.5}$ value and the highest $V_{\max }$ determined for methylated dinucleotides, as shown in Table 1).

\section{HIT-45 only hydrolyzes dinucleoside polyphosphates}

Different nucleotides were tested as HIT-45 substrates to determine if the enzyme could cleave nucleotides other than dinucleotides. Four different mononucleotides $\left(\mathrm{pm}^{7} \mathrm{G}\right.$,

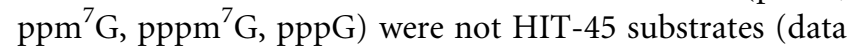
not shown). Capped and uncapped oligonucleotides including cap $4, \mathrm{~m}^{7} \mathrm{GpppAACU}$, and longer RNAs $\left(\mathrm{m}^{7} \mathrm{GpppN}_{15}\right.$ and $\mathrm{m}^{7} \mathrm{GpppN}_{30}$ ) were also not HIT-45 substrates (Table 1). In contrast, a wide variety of unmodified and differently modified dinucleotides (dinucleoside polyphosphates) presented in Table 1 were substrates for the enzyme. Thus, it appears that HIT-45 exclusively hydrolyzes the latter compounds, behaving as a typical Fhit protein/dinucleoside triphosphatase (EC 3.6.1.29).

\section{HIT-45 activity is inhibited by dinucleoside triphosphates independently of their methylation status}

We tested the ability of a wide range of small RNA molecules to block the hydrolysis of $\mathrm{m}^{7} \mathrm{G}^{*} \mathrm{pppG}$ catalyzed 
A
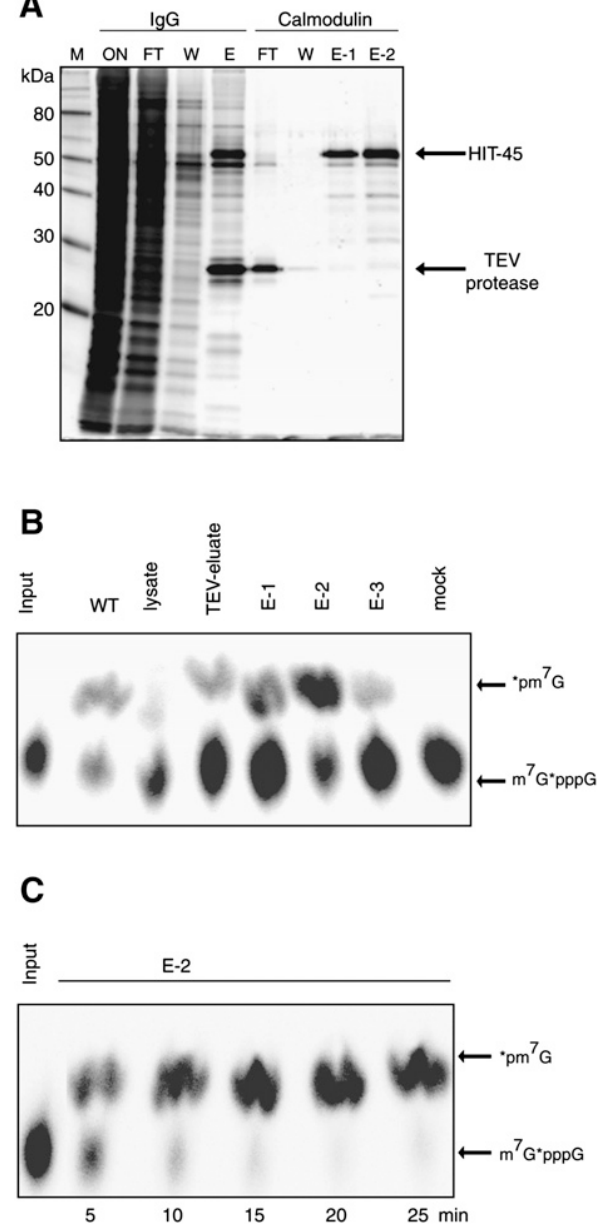

FIGURE 4. HIT-45 purified from trypanosomes hydrolyzes $\mathrm{m}^{7} \mathrm{G}^{*}$ pppG. (A) (IgG lanes) Fractions applied to the IgG resin $(O N)$, flowed through the column $(F T)$, and eluted in the wash $(W)$ or after TEV-protease cleavage $(E)$. Fraction E was separated on Calmodulin resin (Calmodulin lanes) and flow-through, wash, and protein elutions before and after concentration (lanes $E-1, E-2$ ) are shown. Protein size markers (Invitrogen) and TEV protease are labeled on the silver-stained SDS-PAGE gel. (B) TLC analysis of $\mathrm{m}^{7} \mathrm{G}^{*}$ pppG hydrolysis by HIT-45-containing fractions during the purification. Comparison of $\mathrm{m}^{7} \mathrm{G}^{*} \mathrm{pppG}$ hydrolysis by recombinant protein (50 ng; WT lane; see Fig. 3), with T. brucei S100 extract (25 $\mu \mathrm{g}$; lysate), TEV-eluate (60 ng; E from the IgG resin), E-1 (80 ng), and E-2 (130 ng). E-3 eluate (50 $\mathrm{ng}$ ) is from the terminal elution from the calmodulin resin. (Mock) Filtrate $(10 \mu \mathrm{L})$ produced after E-1 concentration to generate E-2. (Input lanes) Substrate incubated in buffer. (C) A time course of E-2 activity.

by HIT-45. As a standard, conditions under which HIT-45 alone converted $50 \%$ of $\mathrm{m}^{7} \mathrm{G}^{*} \mathrm{pppG}$ to ${ }^{*} \mathrm{pm}^{7} \mathrm{G}$ were used (defined as $100 \%$ hydrolysis in all panels). Enzyme inhibitors were added prior to addition of $\mathrm{m}^{7} \mathrm{G}^{*} \mathrm{pppG}$, and the decrease in ${ }^{\star} \mathrm{pm}^{7} \mathrm{G}$ production was measured (Figs. 5, 6). Mononucleotides GTP, $\mathrm{m}^{7} \mathrm{GTP}, \mathrm{m}^{7} \mathrm{GDP}, \mathrm{m}^{7} \mathrm{GMP}$, and benzyl ${ }^{7}$ GTP were poor inhibitors of enzyme activity, as concentrations up to $200 \mu \mathrm{M}$ of each compound inhibited $<80 \%$ of enzyme activity (data not shown).
We then tested the inhibitory effect of seven dinucleotides on HIT-45 hydrolysis of $\mathrm{m}^{7} \mathrm{G}^{*} \mathrm{pppG}$ (Fig. 5). Whereas GpppG and GpppA were robust inhibitors of the enzyme (Fig. 5A,B,G), trimethylguanosine forms of these dinucleotides were 10-fold less inhibitory (Fig. 5D,G). A hypermethylated dinucleotide, $\mathrm{m}^{7} \mathrm{Gpppm}_{3}{ }^{\mathrm{N} 6, \mathrm{~N} 6,2^{\prime} \mathrm{O}} \mathrm{A}$, showed an inhibition profile similar to the $\mathrm{m}_{3}{ }^{\mathrm{N} 2, \mathrm{~N} 2,7} \mathrm{GpppA}$ profile (Fig. 5C,G). These data suggest that both unmethylated and hypermethylated dinucleotides inhibit HIT-45 activity and thus may function as substrates for the enzyme in vivo. Moreover, as both GpppA and $\mathrm{m}_{3}{ }^{\mathrm{N} 2, \mathrm{~N} 2,7} \mathrm{pppA}$ were better inhibitors than were GpppG and $\mathrm{m}_{3}{ }^{\mathrm{N} 2, \mathrm{~N} 2,7} \mathrm{GpppG}$, base composition may affect enzyme recognition of substrates. When we used dinucleotide analogs that contained a methylene group in place of either oxygen atom within the phosphoanhydride bond of $\mathrm{m}^{7} \mathrm{GpppG}$, only a small decrease in $\mathrm{m}^{7} \mathrm{G}^{\star} \mathrm{ppp} \mathrm{G}$ hydrolysis was observed (Fig. 5E-G). Thus, both phosphoanhydride bonds within a dinucleoside triphosphate are required for HIT-45 recognition of substrate.

\section{HIT-45 activity is inhibited by cap 4}

Since the $5^{\prime}$ end of trypanosome mRNAs is cap 4, we determined if cap 4 competed with $\mathrm{m}^{7} \mathrm{G}^{*} \mathrm{pppG}$ for HIT-45 binding (Fig. 6). Low amounts of cap $4(4-10 \mu \mathrm{M})$ were sufficient to block HIT- 45 hydrolysis of $\mathrm{m}^{7} \mathrm{G}^{*}$ pppG; $50 \mu \mathrm{M}$ cap 4 allowed only $7 \%$ conversion of $\mathrm{m}^{7} \mathrm{G}^{\star} \mathrm{pppG}$ to ${ }^{\star} \mathrm{pm}^{7} \mathrm{G}$ (Fig. 6A). In contrast, high amounts of $\mathrm{m}^{7} \mathrm{GpppAACU}$ (cap 4-unmodified) were insufficient to block that reaction; at $50 \mu \mathrm{M}$ concentration it allowed $70 \%$ conversion of $\mathrm{m}^{7} \mathrm{G}^{*} \mathrm{pppG}$ to ${ }^{*} \mathrm{pm}^{7} \mathrm{G}$ (Fig. 6B). In no case did an inhibitor alter the enzyme specificity of the reaction (Fig. 3C; data not shown). A comparison of the inhibition profiles of cap 4 and $\mathrm{m}^{7}$ GpppAACU indicated that cap 4 inhibited enzyme activity much more efficiently than its unmethylated counterpart (Fig. 6C). Thus, cap 4 appears to bind HIT-45, whereas $\mathrm{m}^{7} \mathrm{GpppAACU}$, which lacks the base and sugar modifications of cap 4, does not appear to interact with the enzyme.

\section{DISCUSSION}

HIT-45 is the first enzyme identified in trypanosomes involved in the cleavage of pyrophosphate bonds in dinucleoside polyphosphates, including those that contain caps and can originate from the $5^{\prime}$ ends of mRNAs. The uniqueness of the HIT- 45 protein in trypanosomes, coupled with the distinctiveness of the trypanosome cap structure, implicate HIT-45 as a scavenger decapping enzyme identified in trypanosome mRNA decay. Four observations support this hypothesis. First, HIT-45 is a member of the HIT family of hydrolases that scavenge cap-containing dinucleotides resulting from $3^{\prime}-5^{\prime}$ decay of mRNAs. As 
TABLE 1. Summary of substrate specificity and kinetic parameters for HIT-45

\begin{tabular}{|c|c|c|c|c|}
\hline Nucleotide & $\begin{array}{l}K_{0.5} \\
(\mu \mathrm{M})\end{array}$ & $\begin{array}{l}V_{\max } \\
\left.\text { (relative to } \mathrm{m}^{7} \mathrm{GpppG}\right)\end{array}$ & $\begin{array}{l}\text { Hydrolysis products } \\
\text { (by HPLC analysis) }\end{array}$ & $\begin{array}{c}\text { Reference } \\
\text { (for synthesis) }\end{array}$ \\
\hline $\mathrm{m}^{7} \mathrm{GpppG}$ & 23.4 & 1 & $\mathrm{pm}^{7} \mathrm{G}+\mathrm{ppG}$ & Niedzwiecka et al. (2007) \\
\hline $\mathrm{m}^{7} \mathrm{GpppA}$ & 23.8 & 0.6 & $p m^{7} \mathrm{G}+\mathrm{ppA} \mathrm{ppm}^{7} \mathrm{G}+\mathrm{pA}$ & Jankowska et al. (1996) \\
\hline $\mathrm{m}_{2}{ }^{7,2} \mathrm{O}$ GpppG & 29.7 & 0.6 & $\mathrm{ppm}_{2}{ }^{7,2^{\prime} \mathrm{O}} \mathrm{G}+\mathrm{pG}$ & Jemielity et al. (2003) \\
\hline $\mathrm{m}^{7} \mathrm{Gpppm}{ }^{N 6} \mathrm{~A}$ & 26.5 & 1.1 & $p m^{7} \mathrm{G}+\mathrm{ppm}^{\mathrm{N} 6} \mathrm{~A}$ & Jankowska et al. (1996) \\
\hline $\mathrm{m}_{3}{ }^{\mathrm{N} 2, \mathrm{~N} 2,7} \mathrm{GpppA}$ & 27.8 & 2.8 & $\mathrm{ppm}_{3}{ }^{\mathrm{N} 2, \mathrm{~N} 2,7} \mathrm{G}+\mathrm{pA}$ & Niedzwiecka et al. (2007) \\
\hline $\mathrm{m}_{3}{ }^{\mathrm{N} 2, \mathrm{~N} 2,7} \mathrm{GpppG}$ & 27.2 & 2.8 & $\mathrm{ppm}_{3}{ }^{\mathrm{N} 2, \mathrm{~N} 2,7} \mathrm{G}+\mathrm{pG}$ & Niedzwiecka et al. (2007) \\
\hline $\mathrm{m}^{7} \mathrm{Gpppm}_{3}{ }^{\mathrm{N} 6, \mathrm{~N}^{2}, 2^{\prime} \mathrm{O}} \mathrm{A}$ & 13.2 & 3.3 & $\mathrm{pm}^{7} \mathrm{G}+\mathrm{ppm}_{3}{ }^{\mathrm{N} 6, \mathrm{~N}^{\prime}, 2^{\prime} \mathrm{O}} \mathrm{A}$ & Lewdorowicz et al. (2004) \\
\hline GpppG & 25.9 & 2.8 & pG+ppG & Niedzwiecka et al. (2007) \\
\hline GрppA & $\sim 10$ & ND & $p G+p p A p p G+p A$ & Sawai et al. (1992) \\
\hline ApppA & 6.5 & 3.4 & $p A+p p A$ & Sawai et al. (1992) \\
\hline АрррррА & ND & ND & pA+ppppA & Jemielity et al. (2003) \\
\hline $\mathrm{m}^{7} \mathrm{Gpppm}{ }^{7} \mathrm{G}$ & ND & $(\sim 0.01)$ & $\mathrm{pm}^{7} \mathrm{G}+\mathrm{ppm}^{7} \mathrm{G}$ & Stepinski et al. (1995) \\
\hline $\mathrm{m}_{2}{ }^{\mathrm{N} 2,7} \mathrm{GpppG}$ & ND & ND & $\mathrm{pm}_{2}{ }^{\mathrm{N} 2,7} \mathrm{G}+\mathrm{ppG}$ & Darzynkiewicz et al. (1990) \\
\hline$m^{7} \mathrm{GpCH}_{2} \mathrm{ppG}$ & - & - & Not hydrolyzed & Kalek et al. (2006) \\
\hline$m^{7} \mathrm{GppCH}_{2} \mathrm{pG}$ & ND & $(\sim 0.01)$ & $\mathrm{pm}^{7} \mathrm{G}+\mathrm{pCH} \mathrm{CH}_{2} \mathrm{pG}$ & Kalek et al. (2006) \\
\hline $\mathrm{m}^{7} \mathrm{GppppG}$ & ND & ND & $\mathrm{pm}^{7} \mathrm{G}+\mathrm{pppG}$ & Stepinski et al. (1995) \\
\hline Cap $4 \mathrm{~m}^{7} \mathrm{Gpppm}_{3}{ }^{\mathrm{N6}, \mathrm{N} 6,2^{\prime} \mathrm{O}}$ & - & - & Not hydrolyzed & Lewdorowicz et al. (2004) \\
\hline \multicolumn{5}{|l|}{$\mathrm{Apm}^{2^{\prime} \mathrm{O}} \mathrm{Apm}^{2^{\prime} \mathrm{O}} \mathrm{Cpm}_{2}{ }^{\mathrm{N} 3,2^{\prime} \mathrm{O}} \mathrm{U}$} \\
\hline $\mathrm{m}^{7} \mathrm{GpppApApCpU}$ & - & - & Not hydrolyzed & Yoffe et al. (2004) \\
\hline $\mathrm{m}^{7} \mathrm{Gpppm}_{3}{ }^{\mathrm{N} 6, \mathrm{~N} 6,2^{\prime} \mathrm{O}} \mathrm{Apm}^{2^{\prime} \mathrm{O}} \mathrm{A}$ & - & - & Not hydrolyzed & Lewdorowicz et al. (2007) \\
\hline
\end{tabular}

Hydrolysis products were analyzed by HPLC by matching experimentally obtained peaks with reference compounds. Kinetic analysis was performed by monitoring hydrolysis reactions by fluorimetry and recording the increase in fluorescence intensity as a result of enzymatic cleavage of the phosphoanhydride bond. " $K_{0.5}$ " Represents substrate concentration at half maximal velocity, $V_{\max }$ is the maximal velocity relative to the maximal velocity estimated for $\mathrm{m}^{7} \mathrm{GpppG}$ degradation, and "ND" indicates not determined.

expected for an enzyme that utilizes its histidine triad for phosphoanhydride bond hydrolysis, mutation of the central histidine in the triad inactivates HIT-45. Second, HIT-45 and all HIT family members specifically cleave $5^{\prime}, 5^{\prime \prime \prime}-\mathrm{P}^{1}, \mathrm{P}^{3}$ dinucleotides, and not mononucleotides or 5', $3^{\prime}$-linked oligonucleotides. Third, HIT-45 is likely active in trypanosomes, as suggested by the finding that HIT-45 purified from these organisms is active on capcontaining dinucleotides. Fourth, HIT-45 hydrolyzes $\mathrm{m}^{7} \mathrm{Gpppm}_{3}{ }^{\mathrm{N} 6, \mathrm{~N} 6,2^{\prime} \mathrm{O}} \mathrm{A}$, which is the dinucleotide that would be released after $3^{\prime}-5^{\prime}$ decay of cap 4-containing mRNAs. As $\mathrm{m}^{7} \mathrm{Gpppm}_{3}{ }^{\mathrm{N} 6, \mathrm{~N} 6,2^{\prime} \mathrm{O}} \mathrm{A}$ is unique to trypanosomes, it likely requires a trypanosome-specific decapping enzyme, such as HIT-45, for its hydrolysis. In summary, our data suggest that HIT-45 plays a role in RNA metabolism, possibly by hydrolyzing residual capped nucleotides generated after $3^{\prime}$ to $5^{\prime}$ exonucleolytic decay during mRNA turnover.

The HIT family of nucleotide hydrolases shares an essential Histidine triad motif, which is the sequence $\mathrm{H} \psi \mathrm{H} \psi \mathrm{H} \psi \psi$ (where $\psi$ is a hydrophobic amino acid) that explains their name. The HIT motif is directly involved in the nucleotide binding properties of these proteins. There are several branches within the HIT family, each defined by additional amino acid motifs as well as evolutionary relationships. HIT-45 most closely resembles proteins within the FHIT branch, as it is specific for $5^{\prime}, 5^{\prime \prime \prime}$ dinucleotides and shares with human FHIT and S. pombe Aphlp the signature motifs conserved in some diadenosine polyphosphate hydrolases (Fig. 2; Lima et al. 1997; Ingram et al. 2003). Monomers of $\alpha_{2}$ human FHIT and S. pombe Aph1p are relatively small proteins, $\sim 15 \mathrm{kDa}$ in size. In contrast, HIT-45 contains a large N-terminal extension. There is a precedent for N-terminal extended Fhit proteins in worms and flies. These organisms contain an fHIT protein fusion, designated NitfHIT, in which a nitrilase enzyme is fused to a fHIT protein. The trypanosome HIT-45 resembles this fusion protein in that it contains a well-conserved Fhit region and a large N-terminal domain. However, the $\mathrm{N}$-terminal domain of the trypanosome enzyme is distinctly different from that of NitfHIT and is unique to trypanosomes by bioinformatic analysis. As the amino acid sequence of the HIT-45 "extension" is unique to trypanosomes, it may be responsible for interactions between HIT45 and the trypanosome-specific cap 4 . This could explain why cap 4 , but not $\mathrm{m}^{7}$ GpppAACU, blocks enzyme activity. In summary, we propose that this region may be important in either cap 4 binding or $\mathrm{m}^{7} \mathrm{Gpppm}_{3}{ }^{\mathrm{N} 6, \mathrm{NG}, 2^{\prime} \mathrm{O}} \mathrm{A}$ binding and hydrolysis, both of which are likely to be trypanosomespecific requirements.

The Fhit branch of the HIT family, which contains proteins found exclusively in Eukarya, likely plays a fundamental role in eukaryotic cell metabolism. It is known that FHIT in humans has at least two distinct functions. First, FHIT regulates signaling pathways triggered by specific substrate-enzyme complexes (Trapasso et al. 2003). 


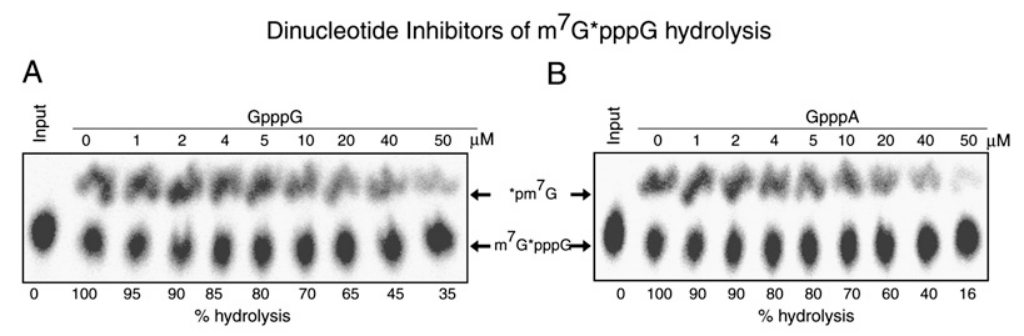

$\mathrm{C}$
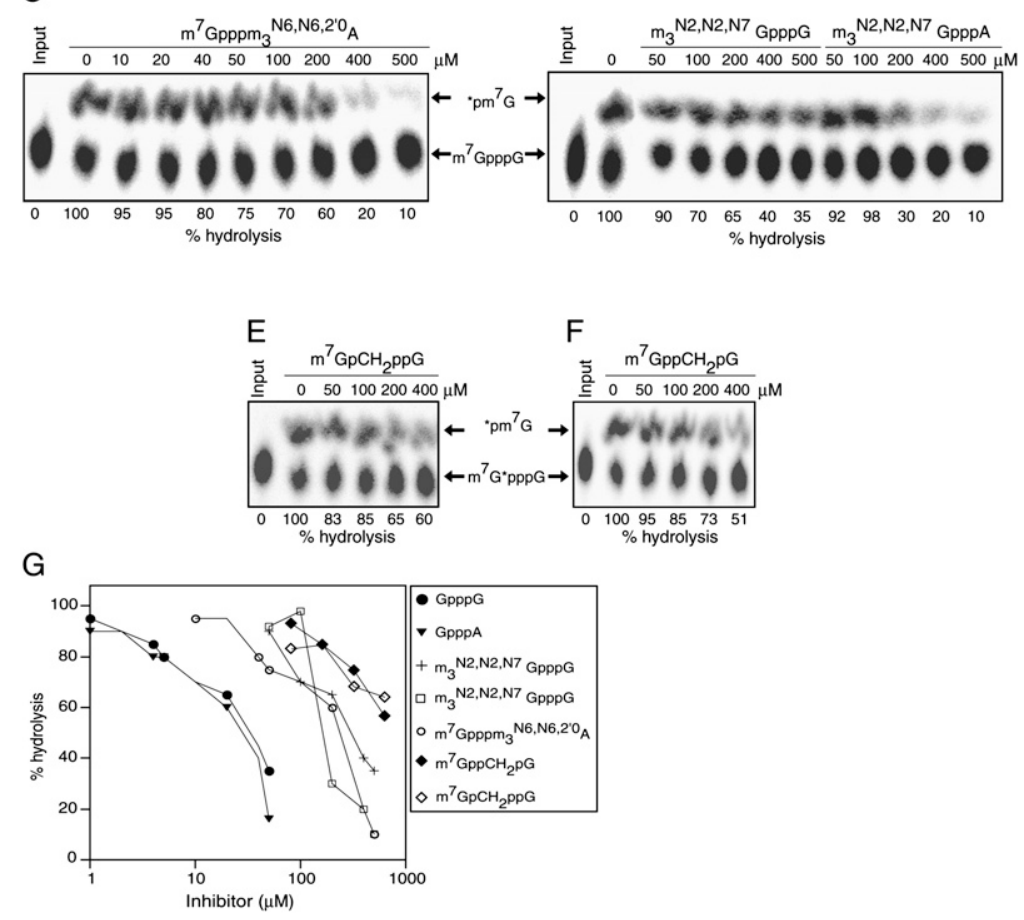

FIGURE 5. Dinucleotide inhibitors of HIT-45. Each panel shows a TLC analysis of substrate to product conversion in the presence of a titrated amount of a different (unlabeled) dinucleotide as indicated: (A) GpppG, (B) GpppA, (C) $\mathrm{m}^{7} \mathrm{Gppp} \mathrm{m}_{3}{ }^{\mathrm{N} 6 \mathrm{~N} 6,2^{\prime} \mathrm{O}} \mathrm{A},(D)$ $\mathrm{m}_{3}{ }^{\mathrm{N} 2, \mathrm{~N} 2,7} \mathrm{GpppG}$ and $\mathrm{m}_{3}{ }^{\mathrm{N} 2, \mathrm{~N} 2,7} \mathrm{GpppA},(E) \mathrm{m}^{7} \mathrm{GpCH}_{2} \mathrm{ppG},(F) \mathrm{m}^{7} \mathrm{GppCH}_{2} \mathrm{pG}$. (G) A graphic comparison of inhibitor effects on $\mathrm{m}^{7} \mathrm{G}^{*} \mathrm{pppG}$ hydrolysis. In all cases, $\mathrm{m}^{7} \mathrm{G}^{*} \mathrm{pppG}$ was preincubated with inhibitor prior to HIT-45 addition. (Input lanes) $\mathrm{m}^{7} \mathrm{G}^{*} \mathrm{pppG}$ incubated with buffer and no enzyme. Percent hydrolysis was calculated as defined in the text and was the average of three independent experiments.

This activity is independent of the enzyme's hydrolase activity. FHIT suppresses tumor formation in humans in the absence of its hydrolysis activity, suggesting that FHIT-dependent signaling cascades, triggered by specific substrate-enzyme complexes, function during cancer surveillance in mammalian cells (Brenner 2002). Similarly, it is possible that cap 4-HIT-45 complexes signal biological activities integral to the metabolic circuitry in trypanosomes. Second, FHIT hydrolyzes diadenosine polyphosphates, which are generated as side products of some aminoacyl tRNA synthetases activity under conditions of cell stress (McLennan 2000; Murphy et al. 2000; Sillero and Sillero 2000). It has been shown that Fhits recognize as substrates several other naturally occurring nucleotides, such as adenosine $5^{\prime}$ phosphosulfate and adenosine $5^{\prime}$ phosphoramidate (Guranowski et al. 2008). Thus, we speculated that HIT-45 functions to turn over $\mathrm{Ap}_{\mathrm{n}} \mathrm{X}$ or related molecules that are produced during intracellular anabolic and catabolic metabolism in the parasite cytoplasm. Trypanosomes require purine acquisition for growth and are avid scavengers of oligonucleotides, nucleosides, and nucleobases. They are also replete with nitrogenous base and nucleoside interconverting enzymes. Thus, it is possible that the hydrolase function of HIT-45 is important for the acquisition and recycling of nucleotides. The high affinity of the enzyme for an array of unmethylated dinucleotides supports this contention.

We envision that during trypanosome mRNA decay, deadenylation of the polyadenylate tail releases an RNA that is readily destroyed by $3^{\prime}$ to $5^{\prime}$ exonucleases within the exosome complex. The exosome complex has been well characterized in trypanosomes (Estevez et al. 2001). In our model, the exosome releases the cap 4 pentanucleotide that is catabolized by phosphodiesterase cleavage between $A_{1}$ and $A_{2}$ and removal of the $2^{\prime}$-O-methylribose modification on $\mathrm{A}_{1}$ to yield $\mathrm{m}^{7} \mathrm{Gpppm}_{3}{ }^{\mathrm{N} 6, \mathrm{~N} 6,2^{\prime} \mathrm{O}} \mathrm{A}$. This hypermethylated dinucleotide is then hydrolyzed to $\mathrm{pm}^{7} \mathrm{G}$ and $\mathrm{ppm}_{3}{ }^{\mathrm{N} 6, \mathrm{~N} 6,2^{\prime} \mathrm{O}} \mathrm{A}$ by HIT-45 (Fig. 7). Our discovery of an enzyme that recognizes a partially catabolized cap 4 is the impetus for searches of the predicted phosphodiesterase and a demethylase activity that would generate $\mathrm{m}^{7} \mathrm{Gpppm}_{3}{ }^{\mathrm{N} 6, \mathrm{~N} 6,2^{\prime} \mathrm{O}} \mathrm{A}$ after exosome activity. Enzymatic pathways that lead to cap 4 metabolism are beginning to be explored (Arhin et al. 2006; Takagi et al. 2007; Zamudio et al. 2007).

Our data illuminate a third function for FHIT proteins, namely that of coordinating mRNA decay and the intracellular signaling by dinucleoside polyphosphates. mRNA decay in trypanosomes probably produces cap 4 and $\mathrm{m}^{7} \mathrm{Gpppm}_{3}{ }^{\mathrm{N} 6, \mathrm{~N} 6,2^{\prime} \mathrm{O}}$ A. In humans, dinucleoside polyphosphates in pancreatic B-cells function in glucose sensing, and in bacteria, they function in the heat-shock response (Lee et al. 1983; Brenner 2002; Rubio-Texeira et al. 2002). Therefore, the control of dinucleoside polyphosphate levels in cells is important for their activities. HIT-45 may modulate $\mathrm{m}^{7} \mathrm{Gpppm}_{3}{ }^{\mathrm{N} 6, \mathrm{~N} 6,2^{\prime} \mathrm{O}} \mathrm{A}$ levels in trypanosomes, linking mRNA decay products with cellular metabolic needs. 

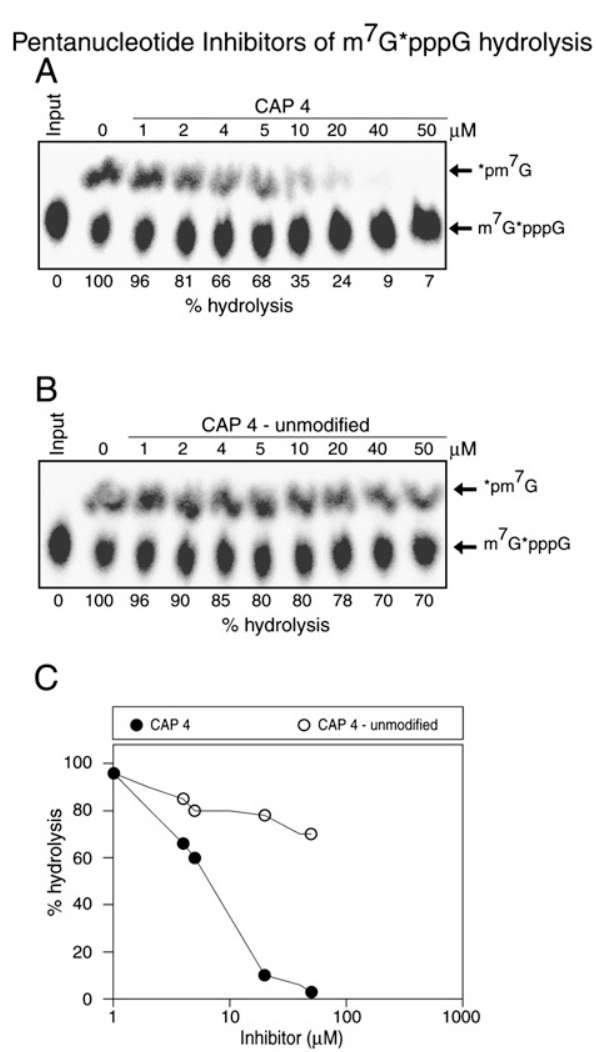

FIGURE 6. Pentanucleotide inhibitors of HIT-45 activity. Each panel shows a TLC analysis of substrate to product conversion in the presence of a titrated amount of a different (unlabeled) inhibitor as indicated: $(A)$ cap $4\left(\mathrm{~m}^{7} \mathrm{Gpppm}_{3}{ }^{\mathrm{N} 6}, \mathrm{~N}^{\mathrm{N}}, 2^{\prime} \mathrm{O} \mathrm{Apm}^{2^{\prime} \mathrm{O}} \mathrm{Apm}^{2^{\prime} \mathrm{O}} \mathrm{C} \mathrm{pm}_{2}{ }^{\mathrm{N} 3}, 2^{\prime} \mathrm{O} \mathrm{U}\right)$, (B) cap 4-unmodified ( $\left.\mathrm{m}^{7} \mathrm{GpppAACU}\right)$. (C) Graphic comparison of inhibitor effects on $\mathrm{m}^{7} \mathrm{G}^{\star} \mathrm{pppG}$ hydrolysis. Percent hydrolysis was calculated as defined in the text and was the average of three independent experiments.

\section{MATERIALS AND METHODS}

\section{Trypanosome cell lines}

The genetically engineered strain $29-13$ of $T$. brucei, which is derived from procyclic (tsetse midgut form) wild-type T. brucei Lister 427 parasites and constitutively expresses T7 RNA polymerase and tetracycline repressor coupled to drug resistance markers, was cultured as previously described (Wirtz et al. 1999). Transfectants containing tetracycline-inducible pHB45 integrated into the parasite genome were selected in $2.5 \mu \mathrm{g} / \mathrm{mL}$ phleomycin 24 $\mathrm{h}$ after electroporation. Stable, clonal cell lines were generated by limiting dilution.

\section{Preparation of Trypanosoma brucei cytoplasmic extracts}

T. brucei procyclic (tsetse midgut form) wild-type Lister strain 427 was cultured as described previously (Wirtz et al. 1999). Extracts (S100 fractions) were prepared as described (Milone et al. 2002, 2004) and dialyzed into Buffer D (20 mM HEPES pH 7.9, $50 \mathrm{mM}$ $\mathrm{KCl}, 0.2 \mathrm{mM}$ EDTA, 20\% glycerol, $1 \mathrm{mM}$ DTT, $1 \mu \mathrm{M}$ each of pepstatin $\mathrm{A}$, leupeptin, and $\mathrm{PMSF}$ ) before storing at $-80^{\circ} \mathrm{C}$.

\section{Preparation of cap analogs}

All modified pentanucleotide, trinucleotide, dinucleotide, monucleotide, and methylene-modified cap analogs were synthesized by the methods referenced in Table 1 .

\section{Preparation of radiolabeled $\mathbf{m}^{7} \mathrm{G}^{*} \mathrm{pppG}$}

Plasmid DNA (pGEM-4, Promega) was digested with KpnI and transcribed in vitro (Milone et al. 2002). RNAs were uniquely labeled at the $\gamma$ phosphate of the cap structure using $\alpha-{ }^{32} \mathrm{P}-\mathrm{GTP}$ and recombinant vaccinia virus capping enzymes. The dinucleotide $\mathrm{m}^{7} \mathrm{G}^{\star}$ pppG ( ${ }^{*}$ indicates position of ${ }^{32} \mathrm{P}$ ) was produced by $\mathrm{P} 1$ nuclease digestion of RNA followed by purification using thinlayer chromatography (van Dijk et al. 2003).

\section{Plasmid constructs and recombinant protein purification}

The T. brucei HIT-45 open reading frame (ORF) from GeneDB locus Tb927.8.2980 was PCR amplified from genomic DNA and cloned into pET15b (Novagen) to produce pET15b-HIT-45. The pET15b-HIT-45-H355N, in which His 355 was replaced with Asn, was generated using the QuickChange mutagenesis system (Stratagene). Plasmid pHB45, which contains a C-terminal tandem affinity protein (TAP) tagged HIT-45, was constructed by introducing the HIT-45-TAP fusion into NruI/BamHI-digested pLEW111 (Wirtz et al. 1999). All plasmid constructs were confirmed by sequencing.

Escherichia coli BL21 cells transfected with pET15b-HIT-45 or variant were used for recombinant protein production (Cohen et al. 2004), and $\mathrm{His}_{6}$-tagged HIT-45 was purified by affinity chromatography using Ni-NTA agarose (Qiagen). HIT-45containing fractions were dialyzed into $20 \mathrm{mM}$ HEPES $\mathrm{pH}$ 7.9, $100 \mathrm{mM} \mathrm{KCl}, 1 \mathrm{mM}$ DTT, $0.2 \mathrm{mM}$ EDTA, 10\% glycerol and stored at $-80^{\circ} \mathrm{C}$. Protein concentrations were estimated by comparing Coomassie staining of the protein with titrated amounts of BSA in adjacent lanes of the gel. The human DcpS ORF in pET-28, a generous gift from Dr. Michael Kiledjian (Liu et al. 2002), was expressed and purified as described above.

\section{Purification of TAP-tagged T. brucei HIT-45}

Two liters of transgenic T. brucei containing the HIT-45-TAP construct were induced with $200 \mathrm{ng} / \mathrm{mL}$ tetracycline, and an $\$ 100$ lysate was prepared and protein was purified using protocols adapted from Rigaut et al. (1999) and Das et al. (2006). Protein was stored in $10 \mathrm{mM}$ Tris $\mathrm{pH} 8.0,150 \mathrm{mM} \mathrm{NaCl}, 0.1 \% \mathrm{NP}-40,1$ mM DTT, $10 \%$ glycerol, and $1 \mu \mathrm{M}$ each of leupeptin, pepstatin, and PMSF.

\section{Decapping assays}

Reaction conditions were as described previously (Zhang et al. 1999). Briefly, a $20 \mu \mathrm{L}$ reaction containing either fraction E-2 (100 nM HIT-45-TAP) or purified pET15b-HIT-45 or variant (200 $\mathrm{nM})$ and $\mathrm{m}^{7} \mathrm{G}^{\star}$ pppG (5-25 nM) was incubated in CE buffer (50 $\mathrm{mM}$ Tris $\mathrm{pH} 7.9,20 \mathrm{mM} \mathrm{KCl}, 30 \mathrm{mM}\left[\mathrm{NH}_{4}\right]_{2} \mathrm{SO}_{4}, 2.5 \mathrm{mM}$ $\mathrm{MgCl}_{2}$ ) for $30 \mathrm{~min}$ at $27^{\circ} \mathrm{C}$ and terminated with $20 \mathrm{mM}$ EDTA. Competition experiments were performed under identical conditions. Titrated amounts of unlabeled inhibitors (1-500 $\mu \mathrm{M})$ were incubated with enzyme for $10 \mathrm{~min}$ before addition of $25 \mathrm{nM}$ 


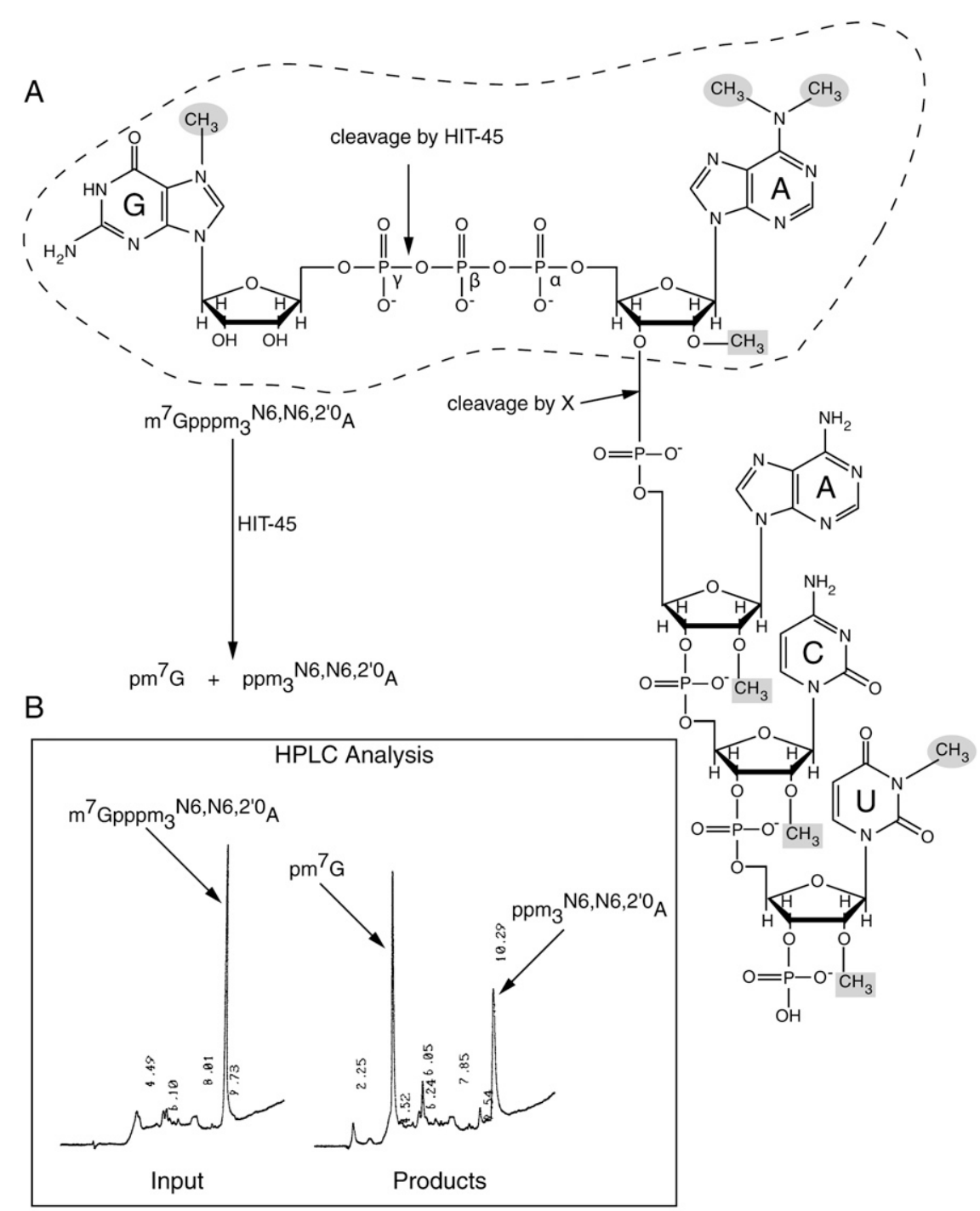

Figure 7 - Banerjee, et al. 2008

FIGURE 7. Hypothetical model for degradation of cap 4. (A) Schematic degradation of cap 4, (B) HIT-45 catalyzed hydrolysis of $\mathrm{m}^{7} \mathrm{Gpppm}_{3}{ }^{\mathrm{N} 6, \mathrm{~N} 6,2^{\prime} \mathrm{O}} \mathrm{A}$ to $\mathrm{m}^{7} \mathrm{Gp}$ and $\mathrm{ppm}_{3}{ }^{\mathrm{N} 6, \mathrm{~N}^{\mathrm{N}}, 2^{\prime} \mathrm{O}} \mathrm{A}$ as determined by HPLC analysis.

$\mathrm{m}^{7} \mathrm{G}^{\star}$ pppG substrate. Inhibitor stocks were $5 \mathrm{mM}$ in deionized water. Product analysis was performed by thin-layer chromatography (TLC). After phenol/chloroform extraction, decapping products were separated on Bakerflex PEI-F-cellulose, pre-run in deionized water, and developed in $750 \mathrm{mM} \mathrm{LiCl}$ (Milone et al. 2002). Quantification was performed using a PhosphorImager and ImageQuant software (Molecular Dynamics), and hydrolysis was quantified by comparing the fraction of $\mathrm{m}^{7} \mathrm{G}^{*} \mathrm{p}$ released from $\mathrm{m}^{7} \mathrm{G}^{\star} \mathrm{pppG}$. For two-dimensional TLC, products were resolved using $1 \mathrm{M}$ acetic acid at $\mathrm{pH} 3.5$ in the first dimension and saturated $\left(\mathrm{NH}_{4}\right)_{2} \mathrm{SO}_{4}$ in the second dimension (Bergman et al. 2004).

\section{Enzymatic digestion of cap analogs with HIT-45}

To determine the kinetic parameters for dinucleotide cap analog hydrolysis, the in vitro decapping assay was used as described above except that five to seven substrate concentrations of unlabeled material (5$120 \mu \mathrm{M}$ ) were present in the reaction. HPLC analysis was used to identify reaction products by matching their retention time with the appropriate peak of a reference compound, as well as by estimating the initial hydrolysis rate of nonmethylated dinucleotide GpppG and $\mathrm{m}^{7} \mathrm{GpppG}$ (as reference substrates). A Spectra-Physics SP 8800 with a Spectra 100 UV monitor, SP 4600 automatic integrator, and a Supelco LC-18-T reversed phase column were utilized in HPLC analysis (Spectra-Physics). The solvent was

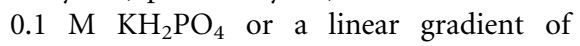
methanol in $0.1 \mathrm{M} \mathrm{KH}_{2} \mathrm{PO}_{4}(0 \%-25 \% \mathrm{v} / \mathrm{v}$ within $15 \mathrm{~min}$ ), and monitoring was performed at $260 \mathrm{~nm}$.

Hydrolysis of other cap analogs was monitored using a fluorimetric method, in which the increase of fluorescence intensity as a result of enzymatic cleavage of pyrophosphate bond in dinucleotides was recorded as previously described (Kalek et al. 2006). The initial rate of hydrolysis was calculated by linear regression of substrate concentration versus time. Fluorescence measurements were carried out on a Perkin-Elmer LS 50B spectrofluorometer, and cuvettes had $4 \mathrm{~mm}$ and $10 \mathrm{~mm}$ path lengths for absorption and emission, respectively. HPLC data directly correlated with fluorometric analysis, as determined by comparing data obtained for the initial hydrolysis rate of $\mathrm{m}^{7} \mathrm{GpppG}$ using both methods.

\section{Estimation of kinetic parameters of fHit-45 using the Hill equation}

The Hill equation $v=V^{\star} a^{\mathrm{h}} /\left(K_{0.5}{ }^{\mathrm{h}}+\mathrm{a}^{\mathrm{h}}\right)$ (where $v$ is the initial velocity; $V$ is the maximal velocity; $a$ is the substrate concentration; $K_{0,5}$ is the substrate concentration that gives a velocity equal to half $V$; and $h$ is the Hill coefficient) was rearranged to the logarithmic form: $\log (v / V-v)=\mathrm{h} \log a-\mathrm{h} \log K_{0,5}$. A plot of $\log (v / V-v)$ against $\log a$ is predicted to give a straight line.

To calculate kinetic parameters from the Hill equation we first estimated a maximal velocity $V$. An approximate $V\left(V_{\text {app }}\right)$ value was obtained from a Lineweaver-Burk plot for data obtained for higher concentrations of substrate. This was used to draw a Hill plot and estimate a Hill coefficient. Subsequently, the Lineweaver-Burk plot was redrawn, substrate concentration values (a) were replaced with $a^{\mathrm{h}}$, and $V_{\max }$ was recalulated. This information was used to redraw the Hill plots and determine the $K_{0,5}$ values.

To compare $V_{\mathrm{o}}$ data obtained for HIT- 45 from different protein purifications, they were normalized against data for $\mathrm{m}^{7} \mathrm{GpppG}$. For kinetic parameters, calculations were used to normalize data. Therefore $V_{\max }$ values, presented in Table 1, are expressed relative to $\mathrm{m}^{7} \mathrm{GpppG}\left(V_{\max }=1\right)$. 


\section{Protein alignments}

Alignments of HIT-45 from T. brucei, T.cruzi, and Leishmania major were performed using CLUSTALW (Thompson et al. 1994). Alignments were generated using the ClustalW program and are represented using GeneDoc (http://www.nrbsc.org/gfx/genedoc/).

The L. major HIT-45 gene was assembled from Lm23_BIN contig795 and LmjF23.1055 sequences.

\section{SUPPLEMENTAL MATERIAL}

Supplemental material can be found at http://www.rnajournal.org.

\section{ACKNOWLEDGMENTS}

We thank Karl Drlica for critical reading of the manuscript. We gratefully appreciate the excellent drawings and figure constructions done by Timothy Linteau. This work was supported by National Institutes of Health-NIAID grant AI535835 to V.B., by grants from the Howard Hughes Medical Institute (No. 55005604) and the Polish Ministry of Sciences and Higher Education (No.2 PO4A 006 28) to E.D., and by a grant from the Polish Ministry of Sciences and Higher Education (PBZ-MNiSW-07/1/2007) to E.D and A.G.

Received October 20, 2008; accepted May 5, 2009.

\section{REFERENCES}

Anderson JS, Parker RP. 1998. The $3^{\prime}$ to $5^{\prime}$ degradation of yeast mRNAs is a general mechanism for mRNA turnover that requires the SKI2 DEVH box protein and $3^{\prime}$ to $5^{\prime}$ exonucleases of the exosome complex. EMBO J 17: 1497-1506.

Arhin GK, Ullu E, Tschudi C. 2006. 2'-O-methylation of position 2 of the trypanosome spliced leader cap 4 is mediated by a $48 \mathrm{kDa}$ protein related to vaccinia virus VP39. Mol Biochem Parasitol 147: 137-139.

Bangs JD, Crain PF, Hashizume T, McCloskey JA, Boothroyd JC. 1992. Mass spectrometry of mRNA cap 4 from trypanosomatids reveals two novel nucleosides. J Biol Chem 267: 9805-9815.

Barnes LD, Garrison PN, Siprashvili Z, Guranowski A, Robinson AK, Ingram SW, Croce CM, Ohta M, Huebner K. 1996. Fhit, a putative tumor suppressor in humans, is a dinucleoside $5^{\prime}, 5^{\prime \prime \prime}$-P1,P3triphosphate hydrolase. Biochemistry 35: 11529-11535.

Bergman N, Milone J, Bates E, Opyrchal M, Bellofatto V, Wilusz J. 2004. Assessing messenger RNA decapping in cellular extracts. In $m R N A$ processing and metabolism: Methods and protocols (ed. D Schoenberg), pp. 181-192. Humana Press, Totowa, NJ.

Berriman M, Ghedin E, Hertz-Fowler C, Blandin G, Renauld H, Bartholomeu DC, Lennard NJ, Caler E, Hamlin NE, Haas B, et al. 2005. The genome of the African trypanosome Trypanosoma brucei. Science 309: 416-422.

Brenner C. 2002. Hint, Fhit, and GalT: Function, structure, evolution, and mechanism of three branches of the Histidine triad superfamily of nucleotide hydrolases and transferases. Biochemistry 41: 9003-9014.

Brenner C, Garrison P, Gilmour J, Peisach D, Ringe D, Petsko GA, Lowenstein JM. 1997. Crystal structures of HINT demonstrate that histidine triad proteins are GalT-related nucleotide-binding proteins. Nat Struct Biol 4: 231-238.

Brenner C, Bieganowski P, Pace HC, Huebner K. 1999. The Histidine triad superfamily of nucleotide-binding proteins. J Cell Physiol 181: 179-187.
Clayton C, Shapira M. 2007. Post-transcriptional regulation of gene expression in trypanosomes and leishmanias. Mol Biochem Parasitol 156: 93-101.

Cohen LS, Mikhli C, Friedman C, Jankowska-Anyszka M, Stepinski J, Darzynkiewicz E, Davis RE. 2004. Nematode $\mathrm{m}^{7} \mathrm{GpppG}$ and $\mathrm{m}_{3}(2,2,7)$ GpppG decapping: Activities in Ascaris embryos and characterization of C. elegans scavenger DcpS. RNA 10: 1609-1624.

Darzynkiewicz E, Stepinski J, Tahara SM, Stolarski R, Ekiel I, Haber D, Neuvonen K, Lehikoinen P, Labadi I, Lönnberg H. 1990. Synthesis, conformation and hydrolytic stability of P1, P3-dinucleoside triphosphates related to mRNA 5'-cap, and comparative kinetic studies on their nucleoside and nucleoside monophosphate analogs. Nucleosides Nucleotides 9: 599-618.

Das A, Li H, Liu T, Bellofatto V. 2006. Biochemical characterization of Trypanosoma brucei RNA polymerase II. Mol Biochem Parasitol 150: $201-210$

El-Sayed NM, Myler PJ, Blandin G, Berriman M, Crabtree J, Aggarwal G, Caler E, Renauld H, Worthey EA, Hertz-Fowler C, et al. 2005. Comparative genomics of trypanosomatid parasitic protozoa. Science 309: 404-409.

Estevez AM, Kempf T, Clayton C. 2001. The exosome of Trypanosoma brucei. EMBO J 20: 3831-3839.

Gu M, Fabrega C, Liu SW, Liu H, Kiledjian M, Lima CD. 2004. Insights into the structure, mechanism, and regulation of scavenger mRNA decapping activity. Mol Cell 14: 67-80.

Guranowski A, Wojdyla AM, Pietrowska-Borek M, Bieganowski P, Khurs EN, Cliff MJ, Blackburn GM, Blaziak D, Stec WJ. 2008. Fhit proteins can also recognize substrates other than dinucleoside polyphosphates. FEBS Lett 582: 3152-3158.

Ingram SW, Barnes LD. 2000. Disruption and overexpression of the Schizosaccharomyces pombe aph1 gene and the effects on intracellular diadenosine 5',5'"'-P1, P4-tetraphosphate (Ap4A), ATP and ADP concentrations. Biochem J 350: 663-669.

Ingram SW, Safrany ST, Barnes LD. 2003. Disruption and overexpression of the Schizosaccharomyces pombe aps1 gene, and effects on growth rate, morphology and intracellular diadenosine $5^{\prime}, 5^{\prime \prime \prime}$ P1,P5-pentaphosphate and diphosphoinositol polyphosphate concentrations. Biochem J 369: 519-528.

Ivens AC, Peacock CS, Worthey EA, Murphy L, Aggarwal G, Berriman M, Sisk E, Rajandream MA, Adlem E, Aert R, et al. 2005. The genome of the kinetoplastid parasite, Leishmania major. Science 309: 436-442.

Jankowska M, Stepinski J, Stolarski R, Wieczorek Z, Temeriusz A, Haber D, Darzynkiewicz E. 1996. 1H NMR and fluorescence studies of new mRNA 5'CAP-analogs. Collect Czech Chem Commun 61: S197-S202.

Jemielity J, Fowler T, Zuberek J, Stepinski J, Lewdorowicz M, Niedzwiecka A, Stolarski R, Darzynkiewicz E, Rhoads RE. 2003. Novel "anti-reverse" cap analogs with superior translational properties. RNA 9: 1108-1122.

Kalek M, Jemielity J, Darzynkiewicz ZM, Bojarska E, Stepinski J, Stolarski R, Davis RE, Darzynkiewicz E. 2006. Enzymatically stable $5^{\prime}$ mRNA cap analogs: Synthesis and binding studies with human DcpS decapping enzyme. Bioorg Med Chem 14: 3223-3230.

Klein MG, Yao Y, Slosberg ED, Lima CD, Doki Y, Weinstein IB. 1998. Characterization of PKCI and comparative studies with FHIT, related members of the HIT protein family. Exp Cell Res 244: 26-32.

Krakowiak A, Pace HC, Blackburn GM, Adams M, Mekhalfia A, Kaczmarek R, Baraniak J, Stec WJ, Brenner C. 2004. Biochemical, crystallographic, and mutagenic characterization of Hint, the AMP-lysine hydrolase, with novel substrates and inhibitors. J Biol Chem 279: 18711-18716.

Lee PC, Bochner BR, Ames BN. 1983. Diadenosine 5',5"' -P1,P4tetraphosphate and related adenylylated nucleotides in Salmonella typhimurium. J Biol Chem 258: 6827-6834.

Lewdorowicz M, Yoffe Y, Zuberek J, Jemielity J, Stepinski J, Kierzek R, Stolarski R, Shapira M, Darzynkiewicz E. 2004. Chemical synthesis and binding activity of the trypanosomatid cap-4 structure. RNA 10: 1469-1478. 
Lewdorowicz M, Jemielity J, Kierzek R, Shapira M, Stepinski J, Darzynkiewicz E. 2007. Solid-supported synthesis of $5^{\prime}$-mRNA CAP-4 from Trypanosomatids. Nucleosides Nucleotides Nucleic Acids 26: 1329-1333.

Lima CD, Klein MG, Hendrickson WA. 1997. Structure-based analysis of catalysis and substrate definition in the HIT protein family. Science 278: 286-290.

Liu H, Rodgers ND, Jiao X, Kiledjian M. 2002. The scavenger mRNA decapping enzyme DcpS is a member of the HIT family of pyrophosphatases. EMBO J 21: 4699-4708.

McLennan AG. 2000. Dinucleoside polyphosphates-Friend or foe? Pharmacol Ther 87: 73-89.

Milone J, Wilusz J, Bellofatto V. 2002. Identification of mRNA decapping activities and an ARE-regulated $3^{\prime}$ to $5^{\prime}$ exonuclease activity in trypanosome extracts. Nucleic Acids Res 30: 4040-4050.

Milone J, Wilusz J, Bellofatto V. 2004. Characterization of deadenylation in trypanosome extracts and its inhibition by poly(A)binding protein Pablp. RNA 10: 448-457.

Mitchell P, Petfalski E, Shevchenko A, Mann M, Tollervey D. 1997. The exosome: A conserved eukaryotic RNA processing complex containing multiple $3^{\prime} \rightarrow 5^{\prime}$ exoribonucleases. Cell 91: 457-466.

Murphy GA, Halliday D, McLennan AG. 2000. The Fhit tumor suppressor protein regulates the intracellular concentration of diadenosine triphosphate but not diadenosine tetraphosphate. Cancer Res 60: 2342-2344.

Niedzwiecka A, Stepinski J, Antosiewicz JM, Darzynkiewicz E, Stolarski R. 2007. Biophysical approach to studies of cap-eIF4E interaction by synthetic cap analogs. Methods Enzymol 430: 209245.

Nuss DL, Furuichi Y, Koch G, Shatkin AJ. 1975. Detection in HeLa cell extracts of a 7-methyl guanosine specific enzyme activity that cleaves $\mathrm{m}^{7} \mathrm{GpppNm}$. Cell 6: $21-27$.

Pace HC, Garrison PN, Robinson AK, Barnes LD, Draganescu A, Rosler A, Blackburn GM, Siprashvili Z, Croce CM, Huebner K, et al. 1998. Genetic, biochemical, and crystallographic characterization of Fhit-substrate complexes as the active signaling form of Fhit. Proc Natl Acad Sci 95: 5484-5489.

Pekarsky Y, Campiglio M, Siprashvili Z, Druck T, Sedkov Y, Tillib S, Draganescu A, Wermuth P, Rothman JH, Huebner K, et al. 1998. Nitrilase and Fhit homologs are encoded as fusion proteins in Drosophila melanogaster and Caenorhabditis elegans. Proc Natl Acad Sci 95: 8744-8749.

Pekarsky Y, Zanesi N, Palamarchuk A, Huebner K, Croce CM. 2002. FHIT: From gene discovery to cancer treatment and prevention. Lancet Oncol 3: 748-754.

Rigaut G, Shevchenko A, Rutz B, Wilm M, Mann M, Seraphin B. 1999. A generic protein purification method for protein complex characterization and proteome exploration. Nat Biotechnol 17: 1030-1032.

Rubio-Texeira M, Varnum JM, Bieganowski P, Brenner C. 2002. Control of dinucleoside polyphosphates by the FHIT-homologous HNT2 gene, adenine biosynthesis and heat shock in Saccharomyces cerevisiae. BMC Mol Biol 3: 7. doi: 10.1186/1471-2199-3-7.

Salehi Z, Geffers L, Vilela C, Birkenhager R, Ptushkina M, Berthelot K, Ferro M, Gaskell S, Hagan I, Stapley B, et al. 2002. A nuclear protein in Schizosaccharomyces pombe with homology to the human tumor suppressor Fhit has decapping activity. Mol Microbiol 46: 49-62.

Sawai H, Shimazu M, Wakai H, Wakabayashi H, Shinozuka K. 1992. Divalent metal ion-catalyzed pyrophosphate bond formation in aqeous solution, synthesis of nucleotides containing polyphosphate. Nucleosides Nucleotides 11: 773-785.

Seraphin B. 1992. The HIT protein family: A new family of proteins present in prokaryotes, yeast and mammals. DNA Seq 3: 177-179.

Shatkin AJ, Manley JL. 2000. The ends of the affair: Capping and polyadenylation. Nat Struct Biol 7: 838-842.

Shuman S. 2002. What messenger RNA capping tells us about eukaryotic evolution. Nat Rev Mol Cell Biol 3: 619-625.

Sillero A, Sillero MA. 2000. Synthesis of dinucleoside polyphosphates catalyzed by firefly luciferase and several ligases. Pharmacol Ther 87: 91-102.

Stepinski J, Bretner M, Jankowska M, Felczac K, Stolarski R, Wieczorek Z, Cai A-L, Rhoads RE, Temeriusz A, Bhaber D, et al. 1995. Synthesis and properties of P1,P2-, P1,P3-, and $\mathrm{P} 1, \mathrm{P} 4$-dinucleoside di-,tri- and tetraphosphate mRNA 5'cap analogs. Nucleosides Nucleotides 14: 717-721.

Tajima M, Nogi Y, Fukasawa T. 1985. Primary structure of the Saccharomyces cerevisiae GAL7 gene. Yeast 1: 67-77.

Takagi Y, Sindkar S, Ekonomidis D, Hall MP, Ho CK. 2007. Trypanosoma brucei encodes a bifunctional capping enzyme essential for cap 4 formation on the spliced leader RNA. J Biol Chem 282: 15995-16005.

Thompson JD, Higgins DG, Gibson TJ. 1994. CLUSTAL W: Improving the sensitivity of progressive multiple sequence alignment through sequence weighting, position-specific gap penalties and weight matrix choice. Nucleic Acids Res 22: 4673-4680.

Trapasso F, Krakowiak A, Cesari R, Arkles J, Yendamuri S, Ishii H, Vecchione A, Kuroki T, Bieganowski P, Pace HC, et al. 2003. Designed FHIT alleles establish that Fhit-induced apoptosis in cancer cells is limited by substrate binding. Proc Natl Acad Sci 100: 1592-1597.

van Dijk E, Le Hir H, Seraphin B. 2003. DcpS can act in the $5^{\prime}-3^{\prime}$ mRNA decay pathway in addition to the $3^{\prime}-5^{\prime}$ pathway. Proc Natl Acad Sci 100: 12081-12086.

Wang Z, Kiledjian M. 2001. Functional link between the mammalian exosome and mRNA decapping. Cell 107: 751-762.

Wirtz E, Leal S, Ochatt C, Cross GA. 1999. A tightly regulated inducible expression system for conditional gene knock-outs and dominant-negative genetics in Trypanosoma brucei. Mol Biochem Parasitol 99: 89-101.

Yoffe Y, Zuberek J, Lewdorowicz M, Zeira Z, Keasar C, Orr-Dahan I, Jankowska-Anyszka M, Stepinski J, Darzynkiewicz E, Shapira M. 2004. Cap-binding activity of an eIF4E homolog from Leishmania. RNA 10: 1764-1775.

Zamudio JR, Mittra B, Foldynova-Trantirkova S, Zeiner GM, Lukes J, Bujnicki JM, Sturm NR, Campbell DA. 2007. The 2'-O-ribose methyltransferase for cap 1 of spliced leader RNA and U1 small nuclear RNA in Trypanosoma brucei. Mol Cell Biol 27: 6084-6092.

Zhang S, Williams CJ, Wormington M, Stevens A, Peltz SW. 1999. Monitoring mRNA decapping activity. Methods 17: 46-51. 

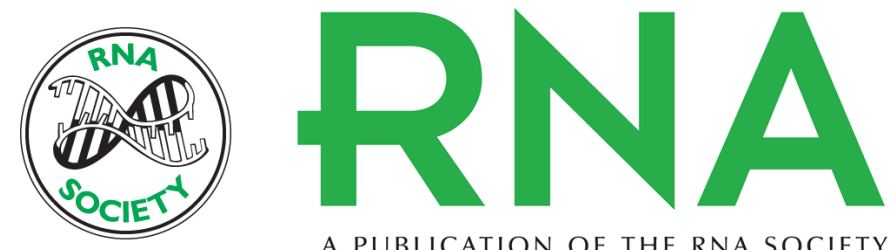

A PUBLICATION OF THE RNA SOCIETY

\section{Identification of the HIT-45 protein from Trypanosoma brucei as an FHIT protein/dinucleoside triphosphatase: Substrate specificity studies on the recombinant and endogenous proteins}

Hiren Banerjee, Jennifer B. Palenchar, Maciej Lukaszewicz, et al.

RNA 2009 15: 1554-1564 originally published online June 18, 2009

Access the most recent version at doi:10.1261/rna.1426609

Supplemental Material

References

License

Email Alerting Service
http://rnajournal.cshlp.org/content/suppl/2009/06/19/rna.1426609.DC1

This article cites 58 articles, 23 of which can be accessed free at: http://rnajournal.cshlp.org/content/15/8/1554.full.html\#ref-list-1

Receive free email alerts when new articles cite this article - sign up in the box at the top right corner of the article or click here. 